\title{
Secondary mould metabolites of Cladosporium tenuissimum, a hyperparasite of rust fungi is
}

\author{
Gianluca Nasini $^{\text {a,* }}$, Alberto Arnone ${ }^{\mathrm{a}}$, Gemma Assante ${ }^{\mathrm{b}}$, Adriana Bava ${ }^{\mathrm{a}}$, \\ Salvatore Moricca ${ }^{c}$, Alessandro Ragazzi ${ }^{d}$ \\ ${ }^{\text {a }}$ CNR-ICRM, Dipartimento di Chimica, Materiali ed Ingegneria Chimica del Politecnico, Via Mancinelli 7, I-20131 Milano, Italy \\ ${ }^{\mathrm{b}}$ Istituto di Patologia Vegetale, Università degli Studi, Via Celoria 2, I-20133 Milano, Italy \\ ${ }^{\mathrm{c}}$ CNR, Istituto per la Protezione delle Piante, Via Madonna del Piano, I- 50019 Sesto Fiorentino Firenze, Italy \\ d Dipartimento di Biotecnologie Agrarie - Sezione Patologia Vegetale, Università, Piazzale delle Cascine 28, I-50144 Firenze, Italy
}

Received 21 October 2003; accepted 8 March 2004

Available online 27 April 2004

\begin{abstract}
Investigation of the extracts of a culture of Cladosporium tenuissimum, a known hyperparasite of several rust fungi, gave rise to the isolation of cladosporols B-E (2-5). Their structure and stereochemistry were elucidated on the basis of ${ }^{1} \mathrm{H}$ and ${ }^{13} \mathrm{C}$ NMR evidence and CD measures.

Cladosporols 1-5 were active in inhibiting the urediniospore germination of the bean rust agent Uromyces appendiculatus. (C) 2004 Elsevier Ltd. All rights reserved.
\end{abstract}

Keywords: Uromyces appendiculatus; Bean rust; Cladosporols; Decaketides; Hyperparasite; Structural elucidation

\section{Introduction}

Suppression of several plant pathogens throughout the world is due to the occurrence of hyperparasites in natural environment. Persistence of these biological agents, as endemic inhabitants of areas, where some disease could develop destructively, effectively contributes to curtail the responsible phytopathogen, thus providing feasible measure of control.

The fruiting, growth and survival of many native-rust fungi are affected by such natural enemies. An example of this kind of nature's own balance is Cladosporium tenuissimum Cooke, hyperparasite of the poplar rust Melampsora larici-populina Kleb., firstly reported in Australia (Sharma and Heather, 1978). Several strains of this dematiaceous hyphomycete were also isolated at different European regions from aeciospores of the

\footnotetext{
The 63 in the series "Secondary Mould Metabolites". For Part 62, see Arnone et al. (2003).

${ }^{*}$ Corresponding author. Tel.: +39-02-2399-3046; fax: +39-02-23993080 .

E-mail address: gianluca.nasini@polimi.it (G. Nasini).
}

heteroecious pine stem rust Cronartium flaccidum (Alb. et Schwein.) G. Winter and its autoic form Peridermium pini (Pers.) Lév. (Moricca et al., 2001). Their taxonomic identification was unambigously performed by means of morphological and molecular characters (Moricca et al., 1999). The intimate contact between the hyperparasite and the rust structures, formation of appressoria and penetration of the fungal host by mechanical forces or lytic enzymes have been demonstrated by SEM and TEM observations (Moricca et al., 2001; Assante et al., 2004). In the frame of a program aiming at investigating the multiple biocontrol mechanisms of $C$. tenuissimum, this paper deals with the chemical characterization of secondary metabolites produced by strain ITT21 of the fungus, and their activity in inhibiting urediniospore germination of the bean rust agent, Uromyces appendiculatus.

\section{Results and discussion}

The EtOAc crude extracts, obtained from cultures of a strain of $C$. tenuissimum designated ITT21 grown on 
Table 1

${ }^{1} \mathrm{H}$ NMR data of compounds 2-5

\begin{tabular}{|c|c|c|c|c|c|c|c|c|c|}
\hline \multirow[t]{2}{*}{ Proton } & \multicolumn{4}{|l|}{$\delta_{\mathrm{H}}$} & \multirow[t]{2}{*}{ Proton } & \multirow[b]{2}{*}{2} & \multirow[b]{2}{*}{3} & \multirow[b]{2}{*}{4} & \multirow[b]{2}{*}{5} \\
\hline & $2^{\mathrm{a}}$ & $\mathbf{3}^{\mathrm{a}}$ & $4^{b}$ & $5^{b}$ & & & & & \\
\hline $2 \mathrm{a}$ & $4.11^{\mathrm{c}}$ & 2.91 & 3.00 & 4.78 & $2 a, 2 b$ & & 15.5 & 15.6 & \\
\hline $2 b$ & & 2.64 & 2.86 & & $2 \mathrm{a}, 3$ & 4.0 & $\mathrm{e}$ & 8.3 & 10.5 \\
\hline $3 a$ & $4.01^{\mathrm{c}}$ & 2.48 & 4.31 & 3.89 & $2 b, 3$ & & $\mathrm{Nd}$ & 4.2 & \\
\hline $3 b$ & & 2.25 & & & 3,4 & & $\mathrm{f}$ & 3.2 & 3.8 \\
\hline 4 & & 5.33 & 5.39 & 5.42 & 6,7 & 8.8 & 8.5 & 8.5 & 8.5 \\
\hline 6 & $7.29^{d}$ & 6.95 & 7.02 & 7.10 & $2^{\prime} \mathrm{a}, 2^{\prime} \mathrm{b}$ & 17.5 & 17.5 & 17.5 & $\mathrm{Nd}$ \\
\hline 7 & $7.17^{d}$ & 6.80 & 6.86 & 6.90 & $2^{\prime} \mathrm{a}, 3^{\prime} \mathrm{a}$ & 5.0 & 6.2 & 6.0 & 6.4 \\
\hline $2^{\prime} \mathrm{a}$ & 2.83 & 2.68 & 2.66 & 2.70 & $2^{\prime} \mathrm{a}, 3^{\prime} \mathrm{b}$ & 9.6 & 6.8 & 8.0 & 6.6 \\
\hline $2^{\prime} \mathrm{b}$ & 2.77 & 2.62 & 2.61 & 2.70 & $2^{\prime} \mathrm{b}, 3^{\prime} \mathrm{a}$ & 5.7 & 6.2 & 6.2 & 6.4 \\
\hline $3^{\prime} \mathrm{a}$ & 2.52 & 2.34 & 2.26 & 2.45 & $2^{\prime} \mathrm{b}, 3^{\prime} \mathrm{b}$ & 5.5 & 6.8 & 5.8 & 6.6 \\
\hline $3^{\prime} \mathrm{b}$ & 2.20 & 2.13 & 2.20 & 2.26 & $3^{\prime} \mathrm{a}, 3^{\prime} \mathrm{b}$ & 13.5 & 13.5 & 13.5 & 13.5 \\
\hline $4^{\prime}$ & 4.92 & 5.46 & 5.58 & 5.35 & $3^{\prime} \mathrm{a}, 4^{\prime}$ & 4.8 & 5.0 & 5.5 & 5.3 \\
\hline $5^{\prime}$ & 6.24 & 6.34 & 6.35 & 6.39 & $3^{\prime} \mathrm{b}, 4^{\prime}$ & 9.2 & 7.2 & 8.0 & 6.8 \\
\hline $6^{\prime}$ & 7.31 & 7.28 & 7.34 & 7.36 & $5^{\prime}, 6^{\prime}$ & 7.7 & 7.7 & 7.7 & 7.7 \\
\hline $7^{\prime}$ & 6.84 & 6.79 & 6.76 & 6.78 & $5^{\prime}, 7^{\prime}$ & 1.2 & 1.2 & 1.2 & 1.2 \\
\hline $2-\mathrm{OH}$ & & & & $4.58^{\mathrm{c}}$ & $6^{\prime}, 7^{\prime}$ & 8.2 & 8.2 & 8.2 & 8.2 \\
\hline $3-\mathrm{OH}$ & & & $3.20^{\mathrm{c}}$ & $4.39^{c}$ & & & & & \\
\hline $4-\mathrm{OH}$ & & 3.95 & $4.52^{\mathrm{c}}$ & $4.58^{c}$ & & & & & \\
\hline $5-\mathrm{OH}$ & 11.42 & 8.70 & 9.20 & 9.00 & & & & & \\
\hline $8^{\prime}-\mathrm{OH}$ & 12.60 & 12.58 & 12.62 & 12.62 & & & & & \\
\hline
\end{tabular}

${ }^{\mathrm{a}} \mathrm{In} \mathrm{CDCl}_{3}$.

${ }^{\mathrm{b}}$ In acetone- $d_{6}$.

c,d Assignments within each column may be interchanged.

e,f The vicinal coupling constants between $\mathrm{H}-2 \mathrm{a}$ and $\mathrm{H}_{2}-3$ are 7.2 and $4.2 \mathrm{~Hz}$ and those between $\mathrm{H}_{2}-3$ and $\mathrm{H}-4$ are 8.2 and $5.0 \mathrm{~Hz}$. Nd, not determined.

sugar-rich malt agar, were separated using a series of silica gel chromatography and stepwise elution with organic solvents; five of the several compounds were completely characterized. The main metabolite 1 represented more than $30 \%$ of the crude extract. It was isolated as a white powder, analysed for $\mathrm{C}_{20} \mathrm{H}_{16} \mathrm{O}_{6}$ and the formula was supported by EIMS $\left(\mathrm{M}^{+}, 352\right)$. The ${ }^{1} \mathrm{H}$ and ${ }^{13} \mathrm{C}$ NMR data of metabolite $\mathbf{1}$ were identical within the experimental error $\left(\Delta \delta_{\mathrm{H}}=0.01, \Delta \delta_{\mathrm{C}}=0.1 \mathrm{ppm}\right.$ and $\Delta \lambda_{\max }=1 \mathrm{~nm}$ ) to those reported for cladosporol, previously isolated from a strain of $C$. cladosporioides and reported as an active inhibitor of the $\beta$-1,3-glucan biosynthesis (Sakagami et al., 1995).

The EI mass spectroscopy of metabolite $\mathbf{2}$ gave a molecular peak at $m / z 350$, with two protons less than in compound 1. A comparison of the ${ }^{1} \mathrm{H}$ and ${ }^{13} \mathrm{C}$ NMR spectra of compound $\mathbf{2}$ with those of $\mathbf{1}$ in $\mathrm{CDCl}_{3}$ (Tables 1 and 2) revealed that this difference is due only to the presence in 2 of a 4-oxo function instead of the $\mathrm{C}(4) \mathrm{HOH}$ grouping. As a matter of fact, reaction of 1 in $\mathrm{CH}_{2} \mathrm{Cl}_{2}$ with pyridinium chloride as oxidant afforded a compound with $[\alpha]$ and ${ }^{1} \mathrm{H}$ NMR values identical to metabolite 2 , which was named cladosporol $\mathrm{B}$.

Compound 3 showed a molecular ion $\left[\mathrm{M}^{+}\right]$at $\mathrm{m} / z$ 338 , compatible with the molecular formula $\mathrm{C}_{20} \mathrm{H}_{18} \mathrm{O}_{5}$ and confirmed by HRMS (Experimental); the IR spectrum afforded the same absorption bands as compound 1 . The ${ }^{1} \mathrm{H}$ and ${ }^{13} \mathrm{C}$ NMR data of 3 and $\mathbf{1}$ in- dicated that these compounds share the same basic skeleton, the only significant difference being the presence in 3 of a $\mathrm{C}(2) \mathrm{H}_{2}-\mathrm{C}(3) \mathrm{H}_{2}$ unit in place of the 2,3-

Table 2

${ }^{13} \mathrm{C}$ NMR data of compounds $\mathbf{2 - 5}$

\begin{tabular}{lrrrr}
\hline \multirow{2}{*}{ Carbon atom } & \multicolumn{2}{c}{$\mathbf{2}$} & $\mathbf{4}$ & \multicolumn{1}{c}{$\mathbf{5}$} \\
\cline { 2 - 5 } & \multicolumn{1}{c}{$\delta_{\mathrm{C}^{\mathrm{a}}}$} & \multicolumn{1}{c}{$\delta_{\mathrm{C}^{\mathrm{a}}}$} & \multicolumn{1}{c}{$\delta_{\mathrm{C}^{\mathrm{b}}}$} & \multicolumn{1}{c}{$\delta_{\mathrm{C}^{\mathrm{b}}}$} \\
\hline 1 & $196.34^{\mathrm{c}}$ & 200.42 & 199.64 & 200.87 \\
2 & $55.69^{\mathrm{d}}$ & 36.62 & 45.41 & 75.90 \\
3 & $55.40^{\mathrm{d}}$ & 30.42 & $69.15^{\mathrm{c}}$ & 73.63 \\
4 & $193.17^{\mathrm{c}}$ & 66.60 & $67.86^{\mathrm{c}}$ & 65.52 \\
$4 \mathrm{a}$ & 114.19 & $130.62^{\mathrm{c}}$ & 129.70 & 129.59 \\
5 & 160.85 & 154.21 & 155.96 & 155.71 \\
6 & 124.01 & 121.12 & 121.07 & 121.16 \\
7 & 139.50 & 131.36 & 131.69 & 132.40 \\
8 & 137.89 & 136.91 & 136.68 & 137.42 \\
$8 \mathrm{a}$ & 130.53 & $130.34^{\mathrm{c}}$ & 132.26 & 130.74 \\
$1^{\prime}$ & 204.70 & 205.79 & 206.49 & 206.67 \\
$2^{\prime}$ & 37.17 & 37.27 & 37.50 & 37.05 \\
$3^{\prime}$ & 30.87 & 30.94 & 31.25 & 31.12 \\
$4^{\prime}$ & 40.11 & 40.04 & 40.80 & 40.63 \\
$4^{\prime} \mathrm{a}$ & 147.00 & 148.59 & 150.13 & 150.00 \\
$5^{\prime}$ & 119.89 & 120.10 & 120.77 & 121.07 \\
$6^{\prime}$ & 136.56 & 136.63 & 137.16 & 136.75 \\
$7^{\prime}$ & 116.28 & 115.60 & 115.84 & 115.85 \\
$8^{\prime}$ & 163.03 & 162.53 & 163.49 & 163.06 \\
$8^{\prime} \mathrm{a}$ & 117.57 & 117.63 & 118.34 & 118.40 \\
\hline${ }^{\mathrm{a}}$ In CDCl In $_{3}$. & & & & \\
${ }^{\mathrm{b}}$ In acetone- $d_{6}$. & & & \\
$\mathrm{c}, \mathrm{d}$ Assignments within each column may be interchanged. &
\end{tabular}


oxirane ring. These values, allowed to assign the structure 3 for cladosporol C.

Cladosporol D 4 was analysed for $\mathrm{C}_{20} \mathrm{H}_{18} \mathrm{O}_{6}$; chemical ionisation mass spectroscopy gave a molecular peak at $m / z 355\left[\mathrm{MH}^{+}\right]$and a base peak at $m / z 336$, due to the loss of a molecule of water. The ${ }^{1} \mathrm{H}$ and ${ }^{13} \mathrm{C}$ NMR data of compound $\mathbf{4}$, when compared with those of $\mathbf{3}$, indicated the presence of a $\mathrm{C}(3) \mathrm{HOH}$ fragment in place of a $\mathrm{CH}_{2}$, the remaining signals being very similar. The vicinal coupling constants of 8.3 and $3.2 \mathrm{~Hz}$ observed between $\mathrm{H}-3$ and $\mathrm{H}-2$ at 3.00 ppm and $\mathrm{H}-3$ and $\mathrm{H}-4$ require that the cylohexenone ring A adopts a chair-like conformation, in which the C-3 and C-4 substituents are pseudoequatorially and pseudoaxially disposed, respectively. It follows that the chiralities at C-3 and C- 4 are $S$ and $R$.

The last metabolite is the compound 5; elemental analysis and EI mass spectroscopy, $m / z\left[\mathbf{M}^{+}\right]=370$, indicated the formula $\mathrm{C}_{20} \mathrm{H}_{18} \mathrm{O}_{7}$. Compound 5, cladosporol $\mathrm{E}$, presented ${ }^{1} \mathrm{H}$ and ${ }^{13} \mathrm{C}$ NMR spectra very similar to those exhibited by $\mathbf{4}$, the only relevant difference being the presence in $\mathbf{5}$ of an additional hydroxy group at C-2. The vicinal coupling constants of 10.5 and $3.8 \mathrm{~Hz}$ observed between $\mathrm{H}-2$ and $\mathrm{H}-3$ and $\mathrm{H}-3$ and $\mathrm{H}-4$, the assignment of which followed from the ${ }^{3} J_{\mathrm{C}, \mathrm{H}}=4 \mathrm{~Hz}$ with $\mathrm{C}-5$, are indicative of pseudoaxial-pseudoaxial and pseudoaxial-pseudoequatorial relationships between
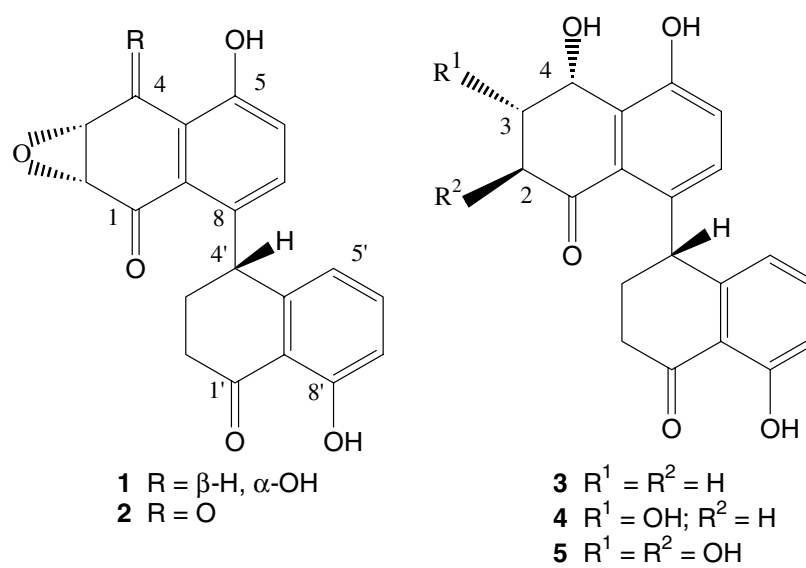

these protons. Thus the chiralities at $\mathrm{C}-2, \mathrm{C}-3$ and $\mathrm{C}-4$ are therefore $S, R$ and $R$, respectively.

To determinate the absolute stereochemistry of cladosporol 1, Sakagami et al. (1995) compared the ${ }^{1} \mathrm{H}-{ }^{1} \mathrm{H}$ coupling constant values and the CD spectrum of 1 with those of (+)-epoxydon and (+)-isoepoxydon (Sekiguchi and Gauche, 1979). The CD behaviour of our compounds 1 and 3-5 paralleled that reported for cladosporol, this fact permitting us to assign the absolute configuration of carbons C-4 and C-4'. Finally, a detailed ${ }^{1} \mathrm{H}-{ }^{1} \mathrm{H}$ coupling constant analysis (Table 1) allowed us to assign the chirality of the remaining carbon centres $\mathrm{C}-2$ and $\mathrm{C}-3$.

Cladosporols 1-5 were tested in vitro against urediniospores of $U$. appendiculatus, the bean rust agent, by means of spore germination assay, and the results are reported in Table 3. Cladosporol B was the most active, since germination was completely inhibited at $50 \mathrm{ppm}$, significantly reduced to more than $90 \%$ at $25 \mathrm{ppm}$, and still low at 12,5 ppm. Cladosporol 1 was more active than cladosporols $\mathrm{C}-\mathrm{E}$, reaching an inhibition value higher than $80 \%$ at the highest concentration.

These compounds, by contributing to the reduction of rust survival structures (number and longevity of spores), are expected to play a major role in the multiple aspects of $C$. tenuissimum biocontrol. Such restriction of the pathogen, in fact, causes a strong alteration of the genetic structure of rust populations, with dramatic effects on the epidemiology of the target disease.

\section{Experimental}

\subsection{General}

Flash column chromatography was performed with Merck silica gel $(0.040-0.63 \mathrm{~mm})$; thin and preparative layer chromatography (TLC and PLC) were performed on precoated plates Merck silica gel $60 \mathrm{~F}_{254}$. CD spectra were measured on a Jasco $\mathrm{J} 6000$ spectropolarimeter. The IR spectra were measured on a Perkin-Elmer 177 spectrophotometer. MS spectra were recorded with a

Table 3

Inhibition percent of Uromyces appendiculatus urediniospore germination on WA by cladosporols at four concentrations ${ }^{\mathrm{a}}$

\begin{tabular}{|c|c|c|c|c|c|}
\hline \multirow[t]{2}{*}{ Metabolite $^{\mathrm{b}}$} & \multicolumn{5}{|c|}{ Metabolite concentration } \\
\hline & $100 \mathrm{ppm}$ & $50 \mathrm{ppm}$ & $25 \mathrm{ppm}$ & $12.5 \mathrm{ppm}$ & Control $^{\mathrm{b}}$ \\
\hline Cladosporol & $84.2 \mathrm{fF}$ & $56.1 \mathrm{dD}$ & $25.9 \mathrm{cC}$ & $10.5 \mathrm{abAB}$ & 20.9 aA \\
\hline Cladosporol B & $100 \mathrm{gG}$ & $100 \mathrm{gG}$ & $92.1 \mathrm{fF}$ & $84.9 \mathrm{fF}$ & $20.9 \mathrm{aA}$ \\
\hline Cladosporol C & $77.6 \mathrm{eE}$ & $50.9 \mathrm{dD}$ & $12.7 \mathrm{abAB}$ & $10.5 \mathrm{abAB}$ & $20.9 \mathrm{aA}$ \\
\hline Cladosporol D & $69.4 \mathrm{deDE}$ & $38.5 \mathrm{cdCD}$ & $36.7 \mathrm{cC}$ & $30.1 \mathrm{cC}$ & 20.9 aA \\
\hline Cladosporol E & $74.8 \mathrm{eE}$ & $50.3 \mathrm{dD}$ & $17.9 \mathrm{bB}$ & $7.2 \mathrm{abAB}$ & $20.9 \mathrm{aA}$ \\
\hline
\end{tabular}

${ }^{a}$ Percent values followed by the same letter within a column are not significantly different according to Duncan's multiple range test; the capital letters refer to $P=0.01$ and the small ones to $P=0.05$.

${ }^{\mathrm{b}}$ Control values are referred to WA amended with solvent (DMSO $0.3 \%$ ) in comparison with WA without solvent. Metabolite values are referred to control. 
Finnigan-Mat TSQ70 instrument and HRMS with a Bruker APEX-QZT ICR and NMR spectra were recorded on a Bruker ARX 400 spectrometer operating at 400.1 MHz for ${ }^{1} \mathrm{H}$ and $100.6 \mathrm{MHz}$ for ${ }^{13} \mathrm{C}$; NMR data were obtained by means of mono and bidimensional experiments. DEPT, HETCOR, and COLOC spectra were performed using the DEPT, XHCORRDC, and COLOC pulse sequences of the software ARX 400.

\subsection{Fungus, production and purification of cladosporols}

The fungal strain ITT21, identified as $C$. tenuissimum Cooke, was recovered from Cronartium flaccidum aeciospore samples collected in 1996 on Pinus pinaster in Tuscany (Italy), as previously described (Moricca et al., 2001). For chemical investigations, the fungus was grown in batch of 40 Roux flasks containing $100 \mathrm{ml}$ MPGGA (malt extract, peptone, glucose, glycerol, agar, 20:2:20:10:15 $\left.\mathrm{g}^{-1}\right)$. After two weeks the cultures were extracted twice with EtOAc-MeOH (99:1). The extracts $(1.4 \mathrm{~g})$ were dried on $\mathrm{Na}_{2} \mathrm{SO}_{4}$, evaporated to dryness and chromatographed on a silica gel column with $\mathrm{CH}_{2} \mathrm{Cl}_{2}$ containing increasing amounts of $\mathrm{MeOH}$ (from $1 \%$ to $15 \%$ ). Collected fractions were further purified by means of PLC to give in order of elution the pure metabolites (the $R_{\mathrm{f}}$ values on silica gel plates are referred to hexane-ether-formic acid (1:1:0.5\% v/v) and $\mathrm{CH}_{2} \mathrm{Cl}_{2}-$ $\mathrm{MeOH}$ (15:1), respectively): cladosporol B 2, $R_{\mathrm{f}} 0.6,0.7$ (10 mg), cladosporol 1, 0.4, 0.4 (310 mg), cladosporol C 3, 0.3, 0.2 (30 mg), cladosporol D 4, 0.2, $0.2(27 \mathrm{mg})$, and cladosporol E 5, 0.1, 0.1 (15 mg).

\subsection{Cladosporol (1)}

Isolated as white powder, mp $192-195{ }^{\circ} \mathrm{C}$ dec., $[\alpha]_{\mathrm{D}}$ $+136\left(\mathrm{MeOH}, c\right.$ 0.1), $\lambda_{\max }(\mathrm{EtOH}) 214,260$ and $338 \mathrm{~nm}$ ( $\varepsilon$ 26,000, 15,000 and 7700); CD (EtOH, c 0.004) 206, 229, 260 and $339 \mathrm{~nm}(\Delta \varepsilon+48,-60,+12.8$ and $+9,4)$; Sakagami's CD values: (EtOH, $c$ 0.02) 206, 230, 260 and $340 \mathrm{~nm}(\Delta \varepsilon+25,-51.6,+8.9$ and +5$)$; found: $\mathrm{C}, 67.5 ; \mathrm{H}$, 4.5. $\mathrm{C}_{20} \mathrm{H}_{16} \mathrm{O}_{6}$ requires: $\mathrm{C}, 68.0 ; \mathrm{H}, 4.6 \%$; EIMS $m / z 352$ $\left[\mathrm{M}^{+}\right](100 \%), 334\left[\mathrm{M}^{+}-18\right](32)$ and $291(43)$.

\subsection{Cladosporol B (2)}

Brown powder, mp $175-180{ }^{\circ} \mathrm{C} ;[\alpha]_{\mathrm{D}}+58\left(\mathrm{CHCl}_{3}, c\right.$ 0.05), $\lambda_{\max }(\mathrm{EtOH}) 207,225 \mathrm{sh}, 261$ and 352 ( 8 32,600, $16,600,16,500$ and 8300); $v_{\max }(\mathrm{KBr}) \mathrm{cm}^{-1} ; 3432,1635$, 1490; found: $\mathrm{C}, 68.4 ; \mathrm{H}, 3.9 . \mathrm{C}_{20} \mathrm{H}_{14} \mathrm{O}_{6}$ requires: $\mathrm{C}$, 68.6; $\mathrm{H}, 4.0 \%$; EIMS $m / z 350\left[\mathrm{M}^{+}\right](100 \%), 303$ (42) and 279 (24); the NMR data are reported in Tables 1 and 2.

\subsection{Cladosporol C (3)}

Yellow-brown powder, mp $172-176{ }^{\circ} \mathrm{C} ;[\alpha]_{\mathrm{D}}+122$ $\left(\mathrm{MeOH}, c\right.$ 0.05); $\lambda_{\max }(\mathrm{EtOH}) 221,260$ and $335 \mathrm{~nm}(\varepsilon$
26,100, 12,800 and 6600); CD (EtOH, c 0.005) 207, 230, 262 and $347 \mathrm{~nm}(\Delta \varepsilon+20.9,-40.9,+6.1$ and +2.7$)$; $v_{\max }(\mathrm{KBr}) \mathrm{cm}^{-1} 3430,1685$ and 1580; HRMS $\mathrm{m} / \mathrm{z}$ 338.3472; $\mathrm{C}_{20} \mathrm{H}_{18} \mathrm{O}_{5}$ requires 338.3492; EIMS $m / z 338$ (45\%), 320 (56) and 302 (100); CIMS (isobutane) $\mathrm{m} / \mathrm{z}$ $339\left[\mathrm{MH}^{+}\right](45 \%)$ and $223(100)$; the NMR data are reported in Tables 1 and 2.

\subsection{Cladosporol D (4)}

Cream solid, mp $110-113{ }^{\circ} \mathrm{C} ;[\alpha]_{\mathrm{D}}+123(\mathrm{MeOH}, c$ $0.05) ; \lambda_{\max }(\mathrm{EtOH}) 222,260$ and $337 \mathrm{~nm}(\varepsilon 28,700,4960$ and 7100); $\mathrm{CD}$ (EtOH, $c$ 0.004) 220, 243, 261 and $337 \mathrm{~nm}$ $(\Delta \varepsilon+22.7,-44.2,+7.4$ and +3.0$) ; v_{\max }(\mathrm{KBr}) \mathrm{cm}^{-1} 3418$, 1683, 1581; found: $\mathrm{C}, 67.3 ; \mathrm{H}, 4.9 . \mathrm{C}_{20} \mathrm{H}_{18} \mathrm{O}_{6}$ requires: $\mathrm{C}$, 67.8; H, 5.1\%; EIMS $m / z 354\left[\mathrm{M}^{+}\right](10 \%), 336(20)$ and 154 (100); the NMR data are listed in Tables 1 and 2.

\subsection{Cladosporol E (5)}

Brown solid, mp $140-145{ }^{\circ} \mathrm{C} ;[\alpha]_{\mathrm{D}}+112(\mathrm{MeOH}, c$ $0.05) ; \lambda_{\max }(\mathrm{EtOH}) 224,260$ and $337 \mathrm{~nm}(\varepsilon 23,000$, 11,360 and 5760); $v_{\max }(\mathrm{KBr}) 3410,1687$ and 1583; CD $($ EtOH, $c$ 0.004) 206, 238, 257 and $340 \mathrm{~nm}(\Delta \varepsilon+15,-56$, +9.3 and +2.2); EIMS $m / z 370\left[\mathrm{M}^{+}\right], 352\left[\mathrm{M}^{+}-18\right], 334$ $\left[\mathrm{M}^{+}-36\right], 316$ and 288; found: $\mathrm{C}, 64.7 ; \mathrm{H}, 5.1$. $\mathrm{C}_{20} \mathrm{H}_{18} \mathrm{O}_{7}$ requires: $\mathrm{C}, 64.9 ; \mathrm{H}, 4.9 \%$; the NMR data are in Tables 1 and 2.

\subsection{Biological assay}

Inhibition of $U$. appendiculatus urediniospore germination was tested on water agar (WA, 1\%) glass slides amended with cladosporols $\mathbf{1}-\mathbf{5}$ at four concentrations $(12.5,25,50$, and $100 \mathrm{ppm})$, in a molar range between 34 and $290 \mu \mathrm{M}$. Compounds were dissolved in DMSO not exceeding $0.3 \%$ of the medium. $U$. appendiculatus urediniospores were collected from infected primary bean leaves, suspended in aqueous $0.01 \%$ Tween $20\left(5 \times 10^{5}\right.$ spores $\mathrm{ml}^{-1}$ ), and pipetted on the slides, which were maintained at $21^{\circ} \mathrm{C}$ in a moist Petri chamber for $24 \mathrm{~h}$. Urediniospore germination was determined from the mean of two independent experiments, each comprising two Petri dishes where 500 urediniospores were counted by scoring 100 propagules per time, by means of light microscopy. Inhibition was calculated as percentage germination in comparison with control on WA slides amended with solvent. Statistical analysis was performed using the Duncan's Multiple Range Test at $P=0.01$ (Mstat-C version 2.00, Michigan State University).

\section{References}

Arnone, A., Candiani, G., Nasini, G., Sinisi, R., 2003. Isolation and structure elucidation of new sesquiterpenes of protoilludane origin 
from the fungus Clavicorona divaricata. Tetrahedron 59, 50335038 .

Assante, G., Maffi, D., Saracchi, M., Farina, G., Moricca, S., Ragazzi, A., 2004. Hystological studies on the mycoparasitism of Cladosporium tenuissimum and urediniospores of Uromyces appendiculatus. Mycol. Res. 108, 170-183.

Moricca, S., Ragazzi, A., Mitchelson, K.R., 1999. Molecular and conventional detection and identification of Cladosporium tenuissimum on two-needle pine rust aeciospores. Can. J. Bot. 77, 339347.

Moricca, S., Ragazzi, A., Mitchelson, K.R., Assante, G., 2001. Antagonism of the two-needle pine stem rust fungi Cronartium flaccidum and Peridermium pini by Cladosporium tenuissimum in vitro and in planta. Phytopathology 91, 457-468.

Sakagami, Y., Sano, A., Hara, O., Mikawa, T., Marumo, S., 1995. Cladosporol, $\beta$-1,3-glucan biosynthesis inhibitor, isolated by the fungus Cladosporium cladosporioides. Tetrahedron Letters 36, 1469-1472.

Sekiguchi, J., Gauche, G.M., 1979. Isoepoxydon, a new metabolite of the patulin pathway in Penicillium urticae. Biochem. J. 182, 445453.

Sharma, J.K., Heather, W.A., 1978. Parasitism of uredospores of Melampsora larici-populina Kleb. by Cladosporium sp. Eur. J. For. Path. 8, 48-54. 